\title{
Sistem Informasi Geografis Pemetaan Lokasi Ideal Taman Nasional di Wilayah Kalimantan Barat
}

\author{
Geographic Information System for Mapping Ideal Location \\ National Park in Kalimantan Barat
}

\author{
David \\ STMIK Pontianak \\ E-mail: David_Liauw@yahoo.com
}

\begin{abstract}
Abstrak
Ketersediaan lahan taman nasional khususnya di wilayah Kalimantan Barat sangat penting mengingat besarnya manfaat yang diperoleh dari keberadaan Taman Nasional. Penelitian ini membuat aplikasi Sistem Informasi Geografis penentuan lokasi ideal pembukaan taman nasional di wilayah Propinsi Kalimantan Barat. Alat bantu dalam menentukan lokasi ideal untuk pembukaan taman nasional baru dengan menggunakan MapInfo, MapWindows, MapWINGIS, Arcview 3.3, dan bahasa pemrograman Visual Studio.Net 2010 dengan metode perancangan waterfall. Analisis spasial untuk menentukan lokasi ideal menggunakan Model Builder sebagai aplikasi dimana user bisa bisa mengembangkan geoprocessing dalam bentuk model. Variabel area hutan, dataran tinggi, kepadatan penduduk, dan wilayah kabupaten dikonversi dalam vector grid. Keempat hasil vector grid tersebut, dilakukan proses arithmatic overlay untuk menentukan daerah yang cocok untuk taman ideal di Propinsi Kalimantan Barat. Hasil penelitian didapatkan bahwa bagian daerah berwarna hijau tua menunjukkan penentuan taman ideal sangat cocok karena kawasan hutan yang masih dominan dan jauh dari kepadatan penduduk. Terdapat tiga daerah dengan tanda persegi panjang berwarna merah yang memenuhi pemetaan lokasi taman ideal. Daerah tersebut masih didominasi area hutan dan masing-masing daerah juga tidak dekat dengan taman lain yang sudah ada.
\end{abstract}

Kata Kunci - Sistem Informasi Geografis, Model Builder, Analisis Spasial, Lokasi Ideal, GeoProcessing.

\begin{abstract}
Land Availability for national parks, especially at the West Kalimantan province is very important considering the magnitude of the benefits derived from the existence of the National Park. This study makes the application of Geographic Information Systems for determining the ideal location opening national parks in the province of West Kalimantan. The Tools used for determining the ideal location for the opening of a new national park consist of MapInfo, MapWindows, MapWINGIS, ArcView 3.3, and Visual Studio.Net 2010 with waterfall design method. Spatial analysis to determine ideal locations using the Model Builder as an application where the user may be developing in the form of geoprocessing models. Variables forest area, highlands, population density, and the district converted into vector grid. Fourth result of the grid vector, arithmatic overlay process is carried out to determine suitable areas for the ideal garden in West Kalimantan Province. The result showed that the section of dark green area shows the determination of the ideal garden is suitable for forest areas that are still dominant and far from overcrowding. There are three rectangular areas with red marks that meet the ideal garden location mapping. The area was still dominated forest areas and each area is also not close to other existing parks.
\end{abstract}

Keywords - Geographic Information System, Model Builder, Spatial Analysis, Ideal Location, GeoProcessing. 


\section{PENDAHULUAN}

Pemilihan lokasi menjadi hal yang penting dalam sebuah usaha pariwisata jangka panjang. Lokasi yang tepat akan mendorong suatu usaha untuk berkembang dengan lebih baik. Usaha pariwisata yang didirikan tanpa mempertimbangkan aspek lokasi yang tepat akan mengalami kesulitan dalam mengembangkan usaha pariwisata tersebut. Ketersediaan lahan taman nasional khususnya pada wilayah Kalimantan barat sangat penting mengingat besarnya manfaat yang diperoleh dari keberadaan Taman Nasional tersebut. Kawasan Taman Nasional ini juga merupakan tempat interaksi sosial bagi masyarakat yang dapat mengurangi tingkat stress akibat beban kerja dan menjadi tempat rekreasi keluarga bagi masyarakat di kalimantan barat.

Selama ini, survey dengan cara turun ke lapangan secara langsung masih menjadi metode yang umum digunakan dalam menentukan lokasi pembukaan taman nasional baru. Permasalahan yang biasanya timbul adalah kurangnya informasi mengenai lokasi yang cocok untuk pembukaan taman nasional yang akurat. Survey secara langsung ke lapangan juga membutuhkan tenaga dan waktu yang tidak sebentar. Survey harus diadakan secara berkali-kali hingga mencapai keputusan akhir pemilihan lokasi. Proses survey secara langsung ke lapangan juga tidak menjamin detailnya informasi yang didapat. Ada kemungkinan terdapat data yang luput atau tidak detail selama proses pengumpulan data melalui survey lapangan. Tidak menutup kemungkinan data seperti kepadatan penduduk, penggunaan tambang, penggunaan lahan atau informasi lokasi taman nasional yang sangat dekat tidak terkumpul secara lengkap pada saat survey dilakukan.

Untuk mengatasi permasalahan tersebut, diperlukan suatu perangkat lunak Sistem Informasi Geografis. Adanya perangkat lunak SIG, dapat membantu pengguna dalam melihat langsung informasi suatu lokasi yang ingin dijadikan lokasi pembukaan taman nasional tanpa harus melakukan survey lapangan. Survey dapat digantikan dengan melihat informasi yang disediakan oleh perangkat lunak GIS tersebut. Informasi seperti kepadatan hutan dan persebarannya, lokasi taman nasional lain yang ada di Propinsi Kalimantan Barat, infrastruktur dan aksesbilitas serta peta penggunaan lahan dapat digunakan oleh pengguna untuk mendapatkan informasi yang lebih baik dan akurat tentang kondisi sekitar suatu lokasi.

Melihat hal tersebut, penulis mencoba untuk merancang sebuah perangkat lunak Sistem Informasi Geografis penentuan lokasi ideal pembukaan taman nasional di wilayah Propinsi Kalimantan Barat, yang dapat digunakan dalam membantu menentukan lokasi ideal tersebut.

Fokus dari objek penelitian ini adalah pembuatan perangkat lunak Sistem Informasi Geografis yang dapat digunakan sebagai alat bantu dalam menentukan lokasi ideal untuk pembukaan taman nasional baru dengan menggunakan MapInfo, MapWindows, MapWINGIS, Arcview 3.3, Model Builder dan bahasa pemrograman Visual Studio.Net 2010 dengan metode perancangan waterfall.

Hazrin, et.al. (2016) melakukan penelitian mengenai distribusi spasial dari insiden demam berdarah studi kasus di PutraJaya. Pada penelitian ini mengintegrasikan sistem informasi geografis dan analisis spatial statistical [1]. Bunch, et.al. (2012) melakukan penelitian GIS untuk pengelolaan lingkungan Sungai Cooum di Chennai, dan mendukung proses partisipatif untuk mengelola lingkungan dan kesehatan di daerah kumuh yang digunakan untuk menunjukkan aplikasi yang tepat dari GIS di India [2]. Penelitian Hassaan (2015) dimaksudkan untuk mengembangkan model berbasis GIS untuk masalah utama limbah padat yang mengancam kualitas lingkungan di daerah perkotaan Mesir. Penelitian ini dapat mengurangi biaya pembuangan limbah padat serta polusi dan menghasilkan energi surplus. GIS digunakan untuk memilih lokasi yang tepat untuk pembangkit listrik pembakaran limbah padat [3]. Penelitian Whanda, et.al. (2015) mempertimbangkan GIS untuk pemetaan lingkungan dan kesehatan manusia yang terkait dengan tumpahan minyak. Metode ini dikembangkan dengan menggunakan multi-kriteria analisis keputusan untuk model, yaitu 1) zona pipa bahaya, 2) radius potensi dampak pipa, dan 3) daerah konsekuensi tinggi dengan empat lapisan atribut, yaitu tanah cover, populasi, sungai dan pipa untuk mendorong partisipasi masyarakat. Model GIS ini diidentifikasi tanah menggunakan daerah, masyarakat dan sungai cenderung rentan terhadap bahaya pipa dan daerah membutuhkan pemantauan rutin dan kemungkinan intervensi [4]. Umar, et.al. (2015) 
melakukan penelitian tentang integrasi penginderaan jauh, sistem informasi geografis (GIS) dan eksplorasi teknik GPS. GIS digunakan untuk menganalisis spasial lokasi yang tepat berkaitan dengan kriteria dievaluasi dan indeks lokasi optimal. Hasil penelitian menunjukkan pola pengembangan lokasi sekolah [5].

Perangkat lunak Sistem Informasi Geografis ini juga menampilkan informasi seperti kota, kecamatan, dan area pertambangan. Fitur-fitur ini, diharapkan mampu menjadi alat bantu dalam pengambilan keputusan bagi pengguna perangkat lunak ini sehingga mampu membantu pengguna dalam menentukan lokasi ideal untuk pembukaan taman nasional baru.

\section{METODE PENELITIAN}

Bentuk penelitian yang digunakan oleh penulis adalah studi kasus, yaitu menjelaskan dan menggambarkan fenomena yang terjadi dalam penentuan lokasi taman nasional yang berada di wilayah Propinsi Kalimantan Barat. Metode penelitian yang digunakan adalah metode Research and Development, yaitu suatu penelitian dimana perangkat lunak yang telah dibuat diuji cobakan dan dilihat tingkat keefektifannya.

MapInfo Professional 10 menggunakan beberapa metode proyeksi peta sekaligus dalam upaya merepresentasikan peta yang dibuat demi menjaga perubahan dan kerusakan pada peta [6]. Proyeksi peta yang digunakan oleh penulis adalah Longitude/ Latitude. Yakni merepresentasikan peta kedalam koordinat geografis yaitu koordinat yang dinyatakan dalam bentuk lintang dan bujur. Lintang dan bujur yang dimaksud merupakan suatu besaran dalam satuan sudut.

Model Builder adalah aplikasi dimana user bisa bisa mengembangkan geoprocessing dalam bentuk model atau kita bisa mengenalnya sebagai diagram atau flowchart [7]. Model dalam geoprocessing (proses analisis spasial) disini diartikan sebagai sekumpulan proses analisa spasial yang melakukan konversi data input untuk menghasilkan output peta (layer/feature class) dengan menggunakan fungsi-fungsi spasial tertentu. Dengan menggunakan Model Builder, model spasial bisa sangat mudah dibuat, dieksekusi, disimpan, dimodifikasi, dan digunakan secara bersamasama. Dengan tool ini, user mampu melakukan hal berikut [7]:

1. Menilai area-area geografis sesuai dengan kriteria yang ditentukan,

2. Melakukan prediksi apa yang akan terjadi pada area-area geografis atas perlakuan yang diberikan padanya,

3. Mendapatkan solusi, mencari pola, dan memperluas pemahaman terhadap sistem yang yang bersangkutan.

Metode perancangan aplikasi Sistem Informasi Geografis yang digunakan penulis adalah menggunakan model sekuensial linier, yang sering disebut juga dengan "model air terjun". Sekuensial linier mengusulkan sebuah pendekatan kepada perkembangan perangkat lunak yang sistematik dan sekuensial yang mulai pada tingkat dan kemajuan sistem pada seluruh analisis, desain, kode, pengujian, dan pemeliharaan.

Ada 6 (enam) aktifitas dari model sekuensial linier yang diterapkan, yaitu [8] \& [9]:

1. Rekayasa dan pemodelan sistem/informasi.

Karena perangkat lunak selalu merupakan bagian dari sebuah sistem yang lebih besar, kerja dimulai dengan membangun syarat dari semua elemen sistem dan mengalokasikan beberapa subset dari kebutuhan ke perangkat lunak tersebut.

2. Analisis kebutuhan perangkat lunak.

Proses pengumpulan kebutuhan diintensifikasikan dan difokuskan, khususnya pada perangkat lunak. Kebutuhan baik untuk sistem maupun perangkat lunak didokumentasikan dan dilihat lagi dengan pelanggan.

3. Desain.

Desain perangkat lunak sebenarnya adalah proses multi langkah yang berfokus pada empat atribut sebuah program yang berbeda; struktur data, arsitektur perangkat lunak, representasi interface, dan detail (algoritma) prosedural. 
4. Generasi Kode.

Desain harus diterjemahkan kedalam bentuk kode-kode program sehingga bisa dibaca dan dimengerti mesin. Jika desain dilakukan dengan cara yang lengkap, pembuatan kode dapat dilakukan secara mekanis.

5. Pengujian.

Sekali kode dibuat, pengujian program dimulai. Dilakukan untuk setiap modul, jika hasil pengujian tidak menemukan adanya masalah, modul-modul yang terpisah diintegrasikan untuk mendapatkan perangkat lunak yang utuh.

6. Pemeliharaan.

Perangkat lunak akan mengalami perubahan setelah disampaikan kepada pelanggan (pengecualian yang mungkin adalah perangkat lunak yang dilekatkan). Pemeliharaan perangkat lunak mengaplikasikan lagi setiap fase program sebelumnya dan tidak membuat yang baru lagi.

\section{HASIL DAN PEMBAHASAN}

Desain yang berisi hasil digitasi Propinsi Kalimantan Barat. Digitasi dilakukan untuk mengetahui letak kota, wilayah Kabupaten Propinsi Kalimantan Barat, letak taman nasional yang sudah dibangun, area taman, area hutan, kepadatan penduduk, dan dataran tinggi. Wilayah Propinsi Kalimantan Barat yang belum mengalami hasil digitasi ditunjukkan pada Gambar 1.

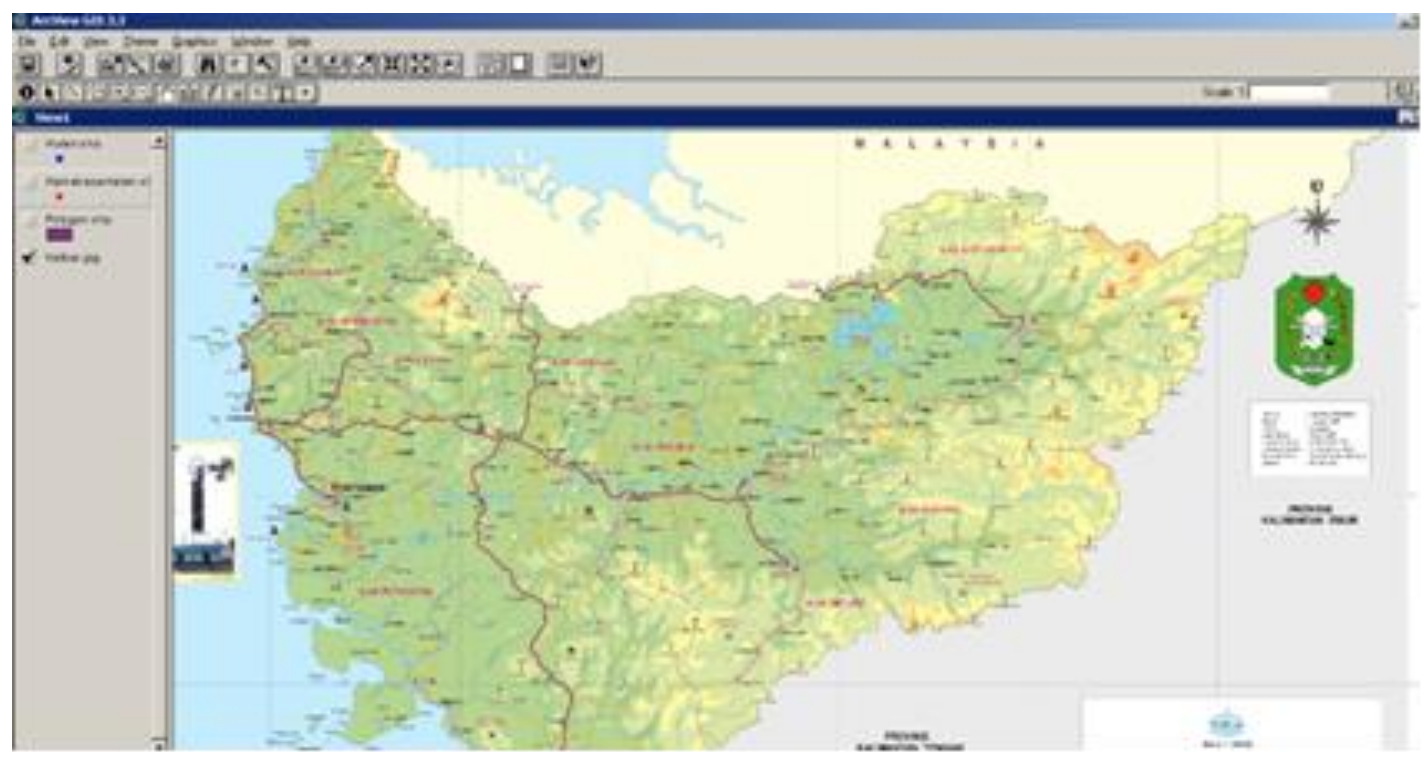

Gambar 1. Peta Kalimantan Barat 
Gambar 2 merupakan wilayah Kabupaten Propinsi Kalimantan Barat yang sudah mengalami hasil digitasi dengan menggunakan theme polygon. Warna kuning adalah wilayah yang terkena select dari proses digitasi.

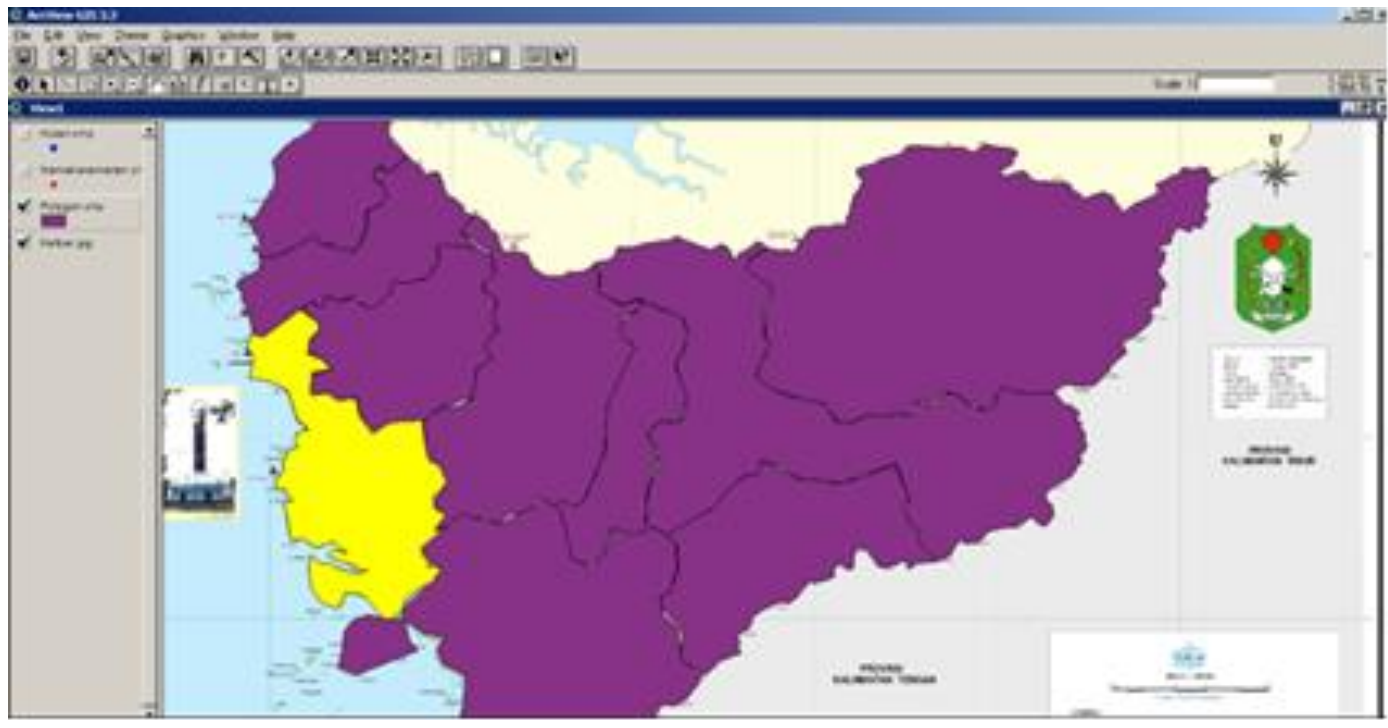

Gambar 2. Hasil Digitasi Theme Polygon pada Peta Kalimantan Barat

Gambar 3 merupakan hasil digitasi kota dan taman nasional dengan menggunakan theme point sebagai tempat. Warna merah untuk kota sedangkan warna biru untuk taman nasional.

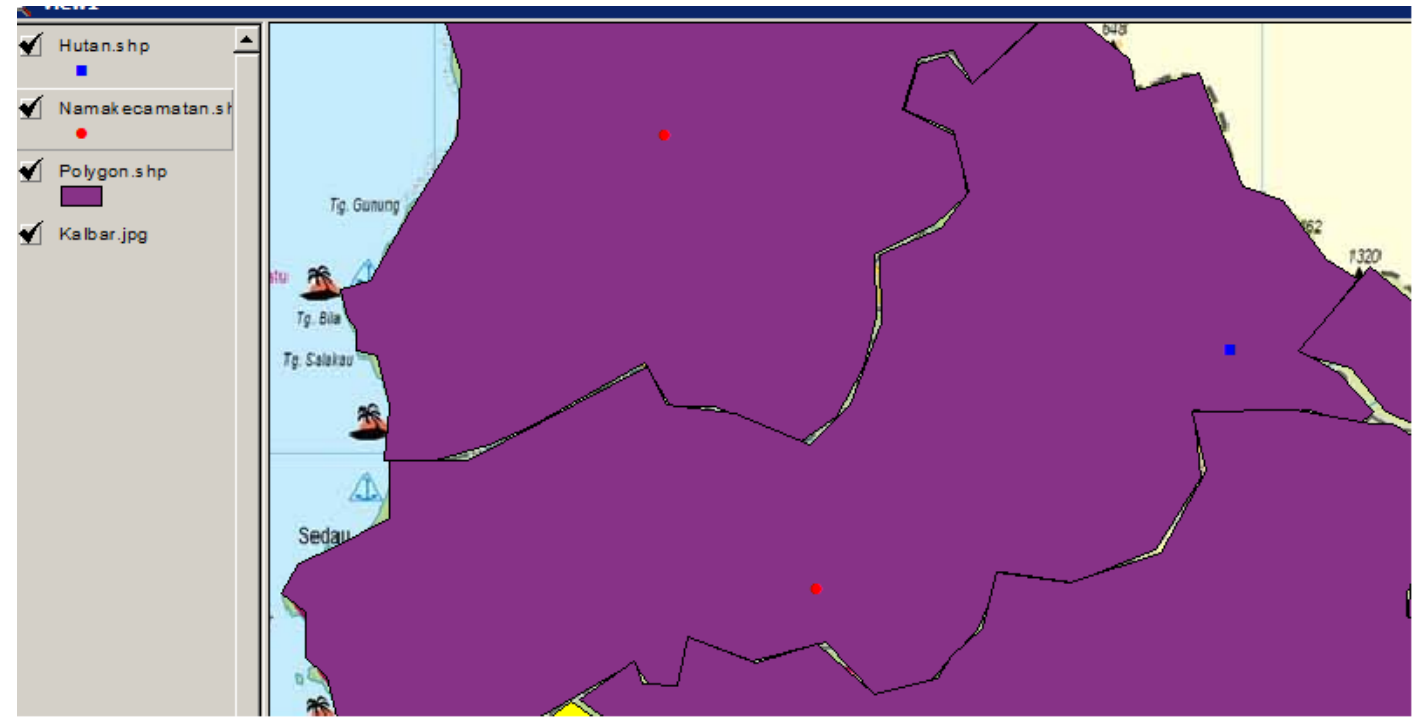

Gambar 3. Hasil Digitasi Theme Point pada Peta Kalimantan Barat 
Citec Journal, Vol. 3, No. 3, Mei 2016 - Juli 2016

Gambar 4 merupakan hasil digitasi keseluruhan dari letak kota, wilayah Kabupaten Propinsi Kalimantan Barat, letak taman nasional yang sudah dibangun, area hutan, area taman, kepadatan penduduk, dan dataran tinggi.

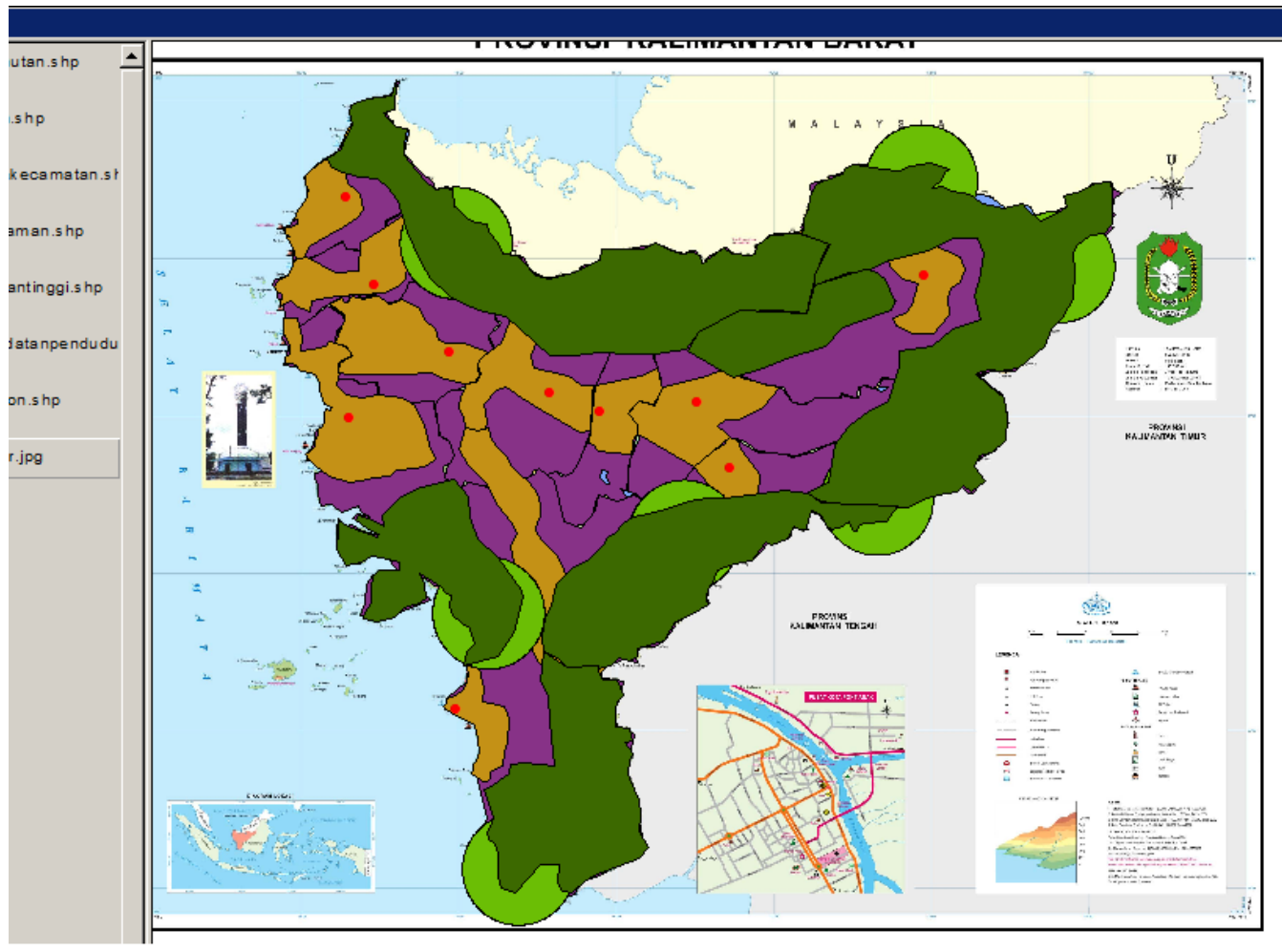

Gambar 4. Hasil Digitasi pada Peta Kalimantan Barat

Gambar 5 merupakan tabel hasil digitasi dari keseluruhan Kabupaten Wilayah Propinsi Kalimantan Barat kecuali untuk area taman yang menjadi kawasan sekitar yang dikunjungi oleh masyarakat.

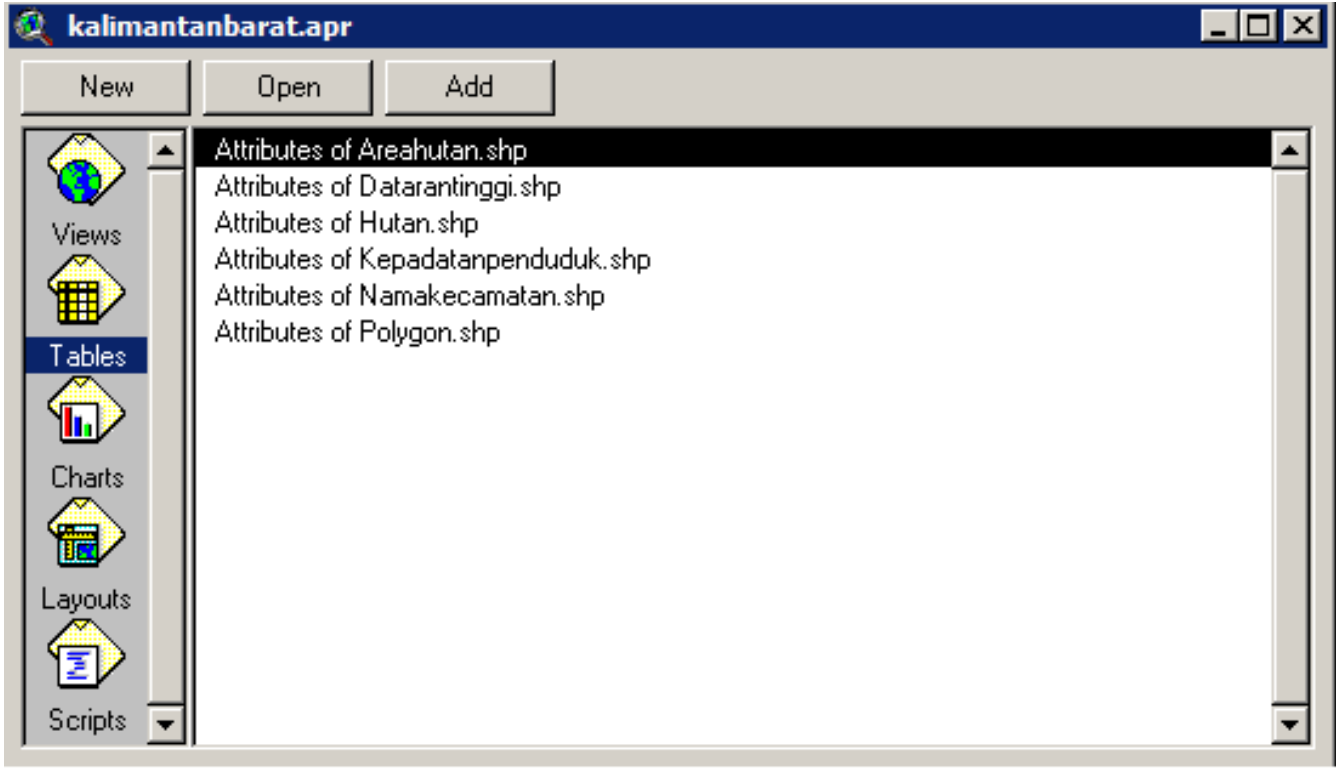

Gambar 5. Tabel Hasil Digitasi pada Peta Kalimantan Barat 
Gambar 6 merupakan tabel hasil digitasi dari daerah Kabupaten Propinsi Kalimatan Barat dengan shape polygon sebagai daerah, id sebagai patokan nomor, kabupaten yang menjadi nama kabupaten, dan skor sebagai lahan yang cocok untuk membangun sebuah taman.

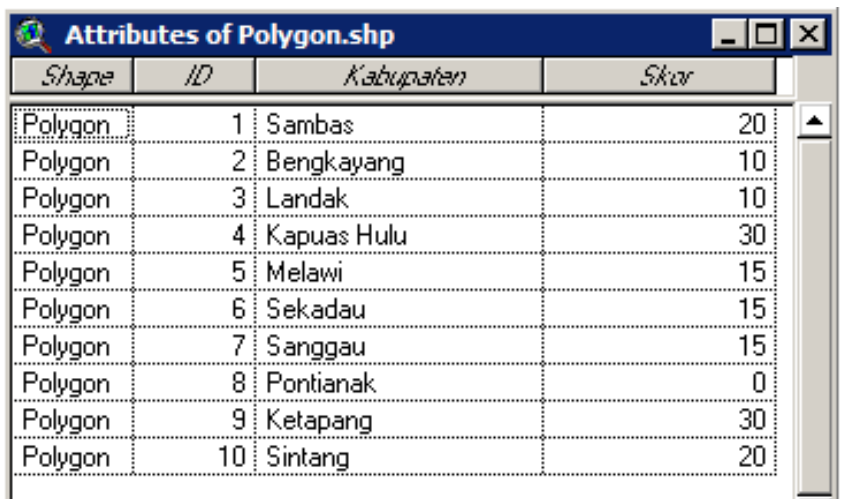

Gambar 6. Hasil Digitasi Shape Polygon Daerah Kalimantan Barat

Gambar 7 merupakan tabel hasil digitasi dari nama kota Propinsi Kalimatan Barat dengan shape point sebagai tempat, id sebagai patokan nomor, dan nama kota yang menjadi keterangan.

\begin{tabular}{|c|c|c|c|}
\hline \multicolumn{4}{|c|}{32 Attributes of Namakecamatan.shp } \\
\hline \multicolumn{4}{|c|}{ 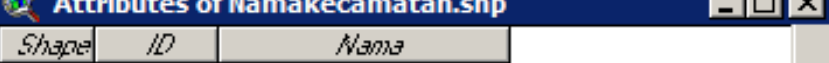 } \\
\hline Point & 1 & Sambas & $\Delta$ \\
\hline Point & 2 & Bengkayang & \\
\hline Point & 3 & Ngabang & \\
\hline Point & 4 & Pontianak & \\
\hline Point & 5 & Ketapang & \\
\hline Point & 6 & Sanggau & \\
\hline Point & 7 & Sekadau & \\
\hline Point & 8 & Sintang & \\
\hline Point & 9 & Putussibau & \\
\hline Point & 10 & Nangapinoh & \\
\hline
\end{tabular}

Gambar 7. Hasil Digitasi Shape Point Daerah Kalimantan Barat

Gambar 8 merupakan adalah tabel hasil digitasi dari taman nasional di wilayah Propinsi Kalimatan Barat dengan shape point sebagai tempat, id sebagai patokan nomor, dan nama taman yang menjadi keterangan.

\begin{tabular}{|c|c|c|c|}
\hline \multicolumn{3}{|c|}{2 Attributes of Hutan.shp } & \multirow[t]{2}{*}{$-10 x$} \\
\hline$S / 3,702$ & 10 & NanOT: & \\
\hline Point & 1 & Taman Nasional Muara Kendawar & \multirow[t]{7}{*}{$\Delta$} \\
\hline Point & 2 & Taman Nasional Gunung Palung & \\
\hline Point & 3 & Taman Nasional Bukit Perai & \\
\hline Point & 4 & Taman Nasional Gunung Niut & \\
\hline Point & 5 & Taman Nasional Gunung Bentuan & \\
\hline Point & 6 & Taman Nasional Batung Kerihun & \\
\hline Point & 7 & Taman Nasional Bukit Raya / Buk & \\
\hline
\end{tabular}

Gambar 8. Hasil Digitasi Taman Nasional Daerah Kalimantan Barat 
Citec Journal, Vol. 3, No. 3, Mei 2016 - Juli 2016

ISSN: 2354-5771

Gambar 9 merupakan tabel hasil digitasi dari area hutan, kepadatan penduduk, dan dataran tinggi. Area hutan memiliki skor 80 yang memiliki kecocokan daerah untuk taman. Kepadatan penduduk memiliki skor 20 dengan operator minus dimana wilayah untuk taman ideal harus jauh dari permukiman penduduk. Dataran tinggi memiliki skor 10 dengan operator minus sama seperti kepadatan penduduk dikarenakan lokasi taman ideal tidak cocok dibangun di dataran tinggi .

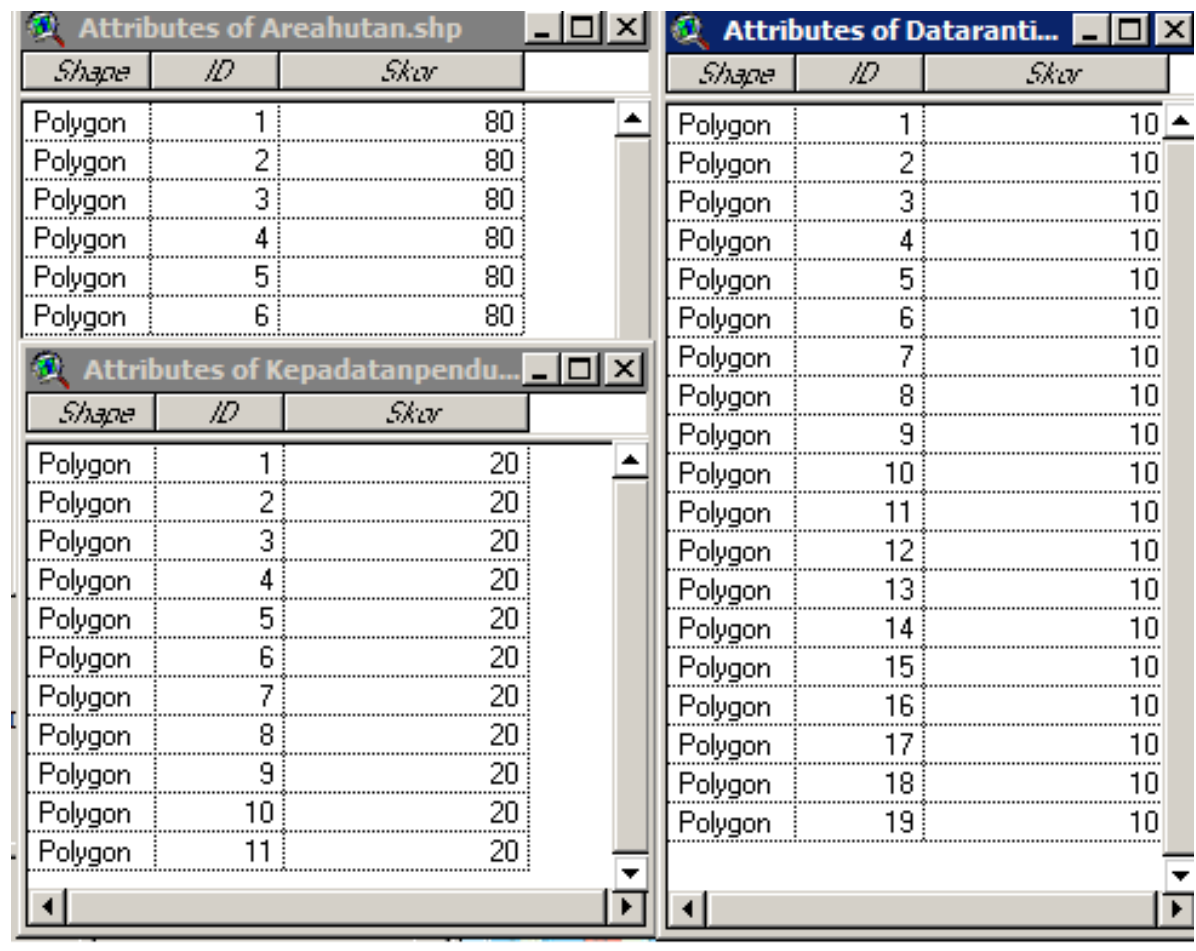

Gambar 9. Hasil Digitasi Area Hutan, Kepadatan Penduduk, dan Dataran Tinggi

Hasil digitasi dan database yang telah jadi kemudian di tampilkan dalam bentuk flowchart. Flowchart atau diagram alir merupakan sebuah diagram dengan simbol-simbol grafis yang menyatakan aliran algoritma atau proses yang menampilkan langkah-langkah yang disimbolkan dalam bentuk kotak, beserta urutannya dengan menghubungkan masing masing langkah tersebut menggunakan tanda panah. Diagram ini bisa memberi solusi selangkah demi selangkah untuk penyelesaian masalah yang ada di dalam proses atau algoritma tersebut.

Analisis yang digunakan dalam penelitian ini adalah adalah analisis spasial melalui aplikasi Sistem Informasi Geografis (SIG) untuk mengidentifikasi lokasi taman nasional yang ideal melalui Model Builder. Perangkat lunak ArcGIS menyediakan aplikasi ModelBuilder yang dapat digunakan untuk membuat Macro, sebuah program yang dapat digunakan untuk mengotomatisasikan dan mendokumentasikan alur kerja dari proses-proses geoprocessing Diagram alir analisis spasial dapat dilihat pada Gambar 10. 


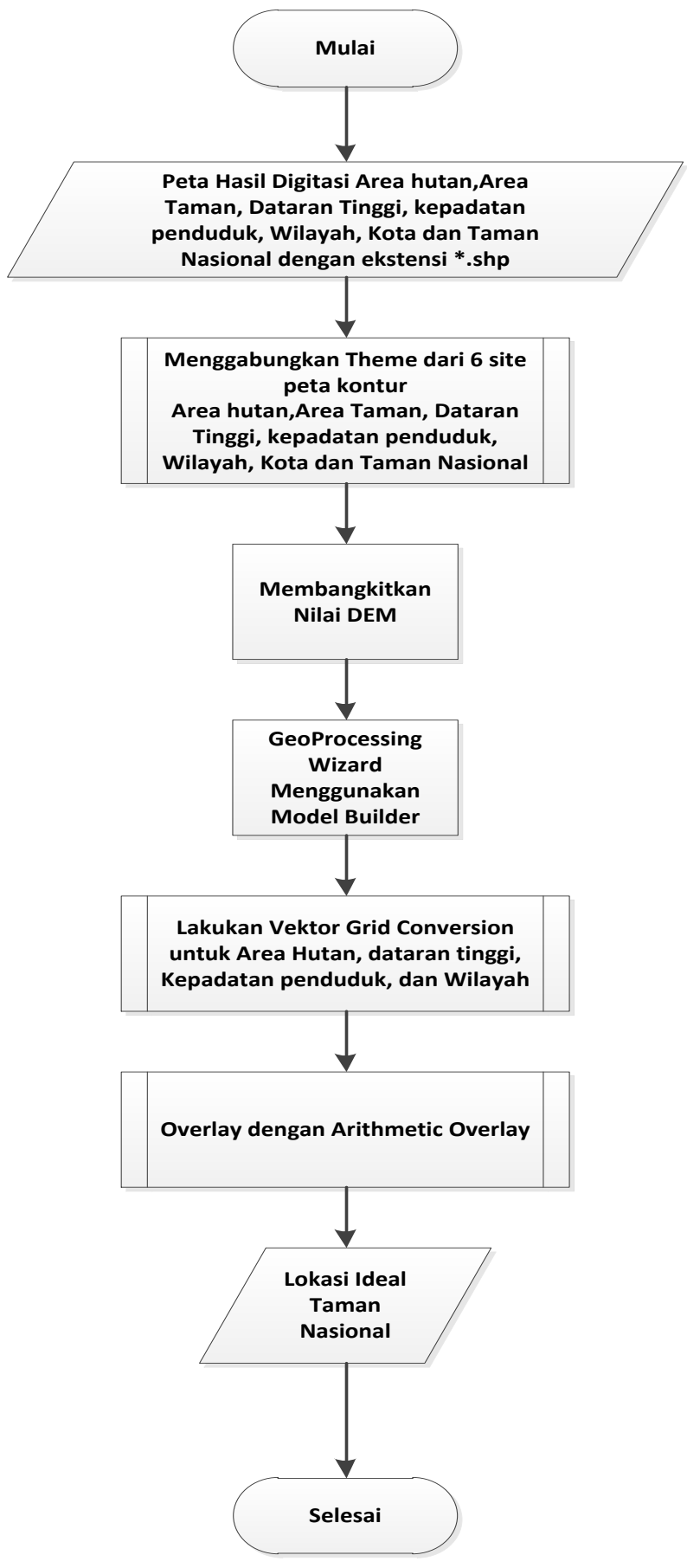

Gambar 10. Diagram Alir Analisis Spasial

Model flowchart sendiri dapat ditemukan dalam aplikasi ArcView GIS 3.3 dengan menginput extension ModelBuilder dan spatial analyzer. Tampilan flowchart yang sudah di ModelBuilder dimana area hutan, dataran tinggi, kepadatan penduduk, dan wilayah kabupaten dikonversi dalam vector grid ditunjukkan pada Gambar 11. Kemudian dari keempat hasil vector grid tersebut, dilakukan proses arithmatic overlay untuk menentukan daerah yang cocok untuk taman ideal di Propinsi Kalimantan Barat. Hasil file overlay bernama Taman Ideal. 
Citec Journal, Vol. 3, No. 3, Mei 2016 - Juli 2016

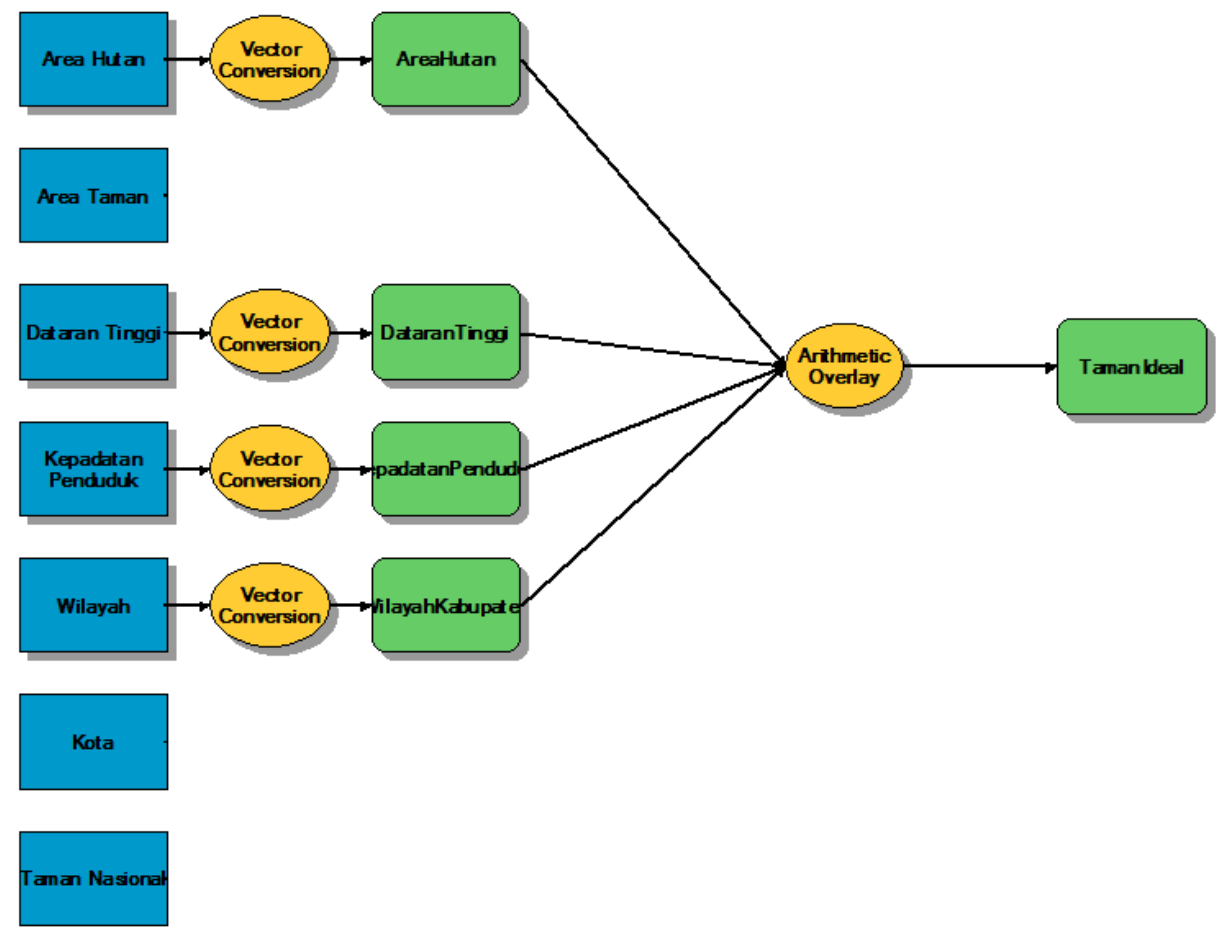

Gambar 11. Model Builder Taman Nasional Ideal

ModelBuilder yang sudah jadi kemudian dijalankan dalam aplikasi ArcView GIS 3.3.exe. Hasil dari ModelBuilder dan dibuat dalam view baru ditunjukkan pada Gambar 12.

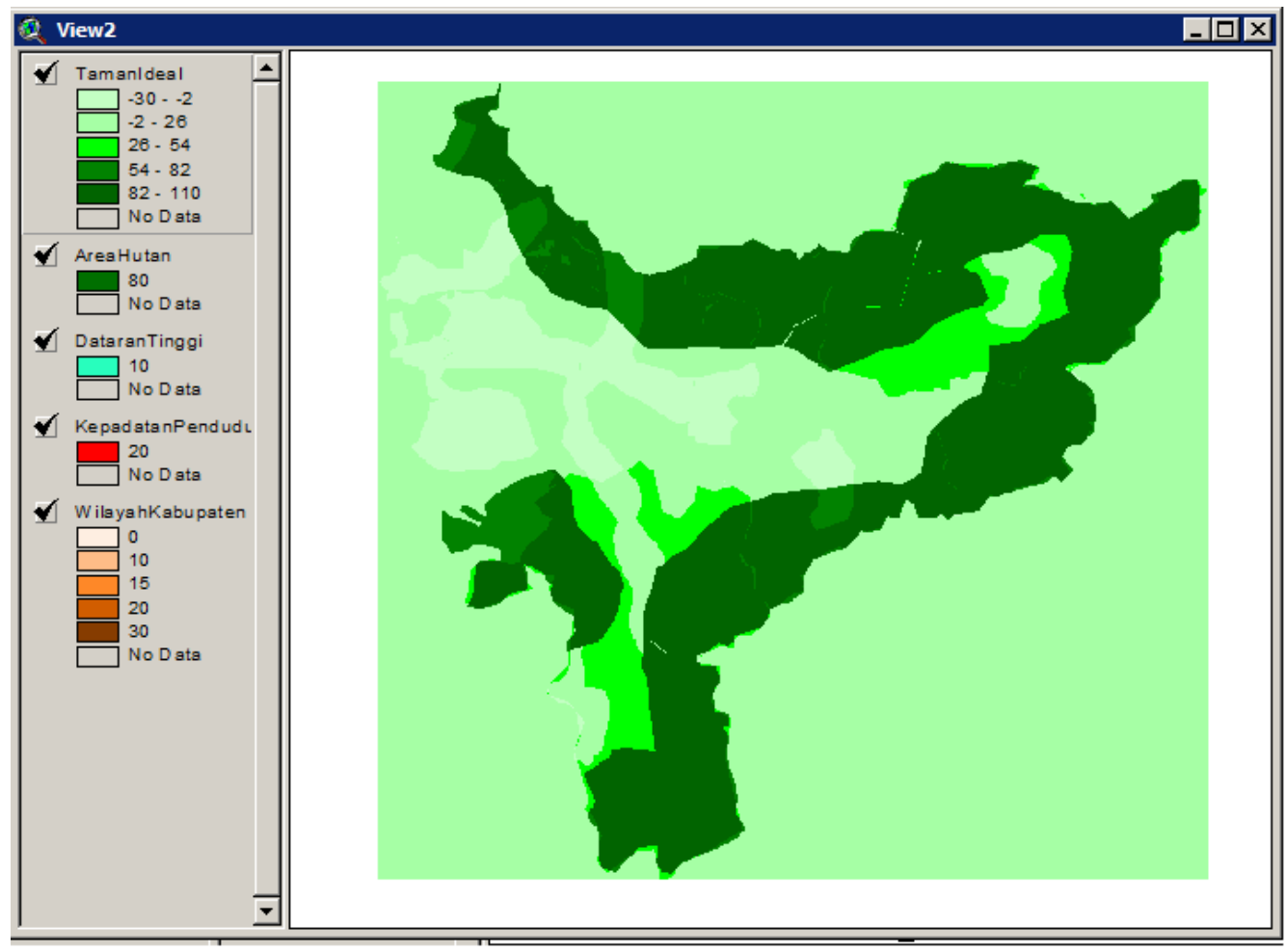

Gambar 12. Hasil Analisis Model Builder Taman Nasional Ideal 
Data hasil digitasi selanjutnya akan diproses dalam pembuatan aplikasi Sistem Informasi Geografis dengan menggunakan bahasa pemrograman Visual Studio.Net 2010. Gambar 13 merupakan tampilan awal form utama dari program Aplikasi GIS untuk penempatan lokasi taman ideal di wilayah Propinsi Kalimantan Barat.

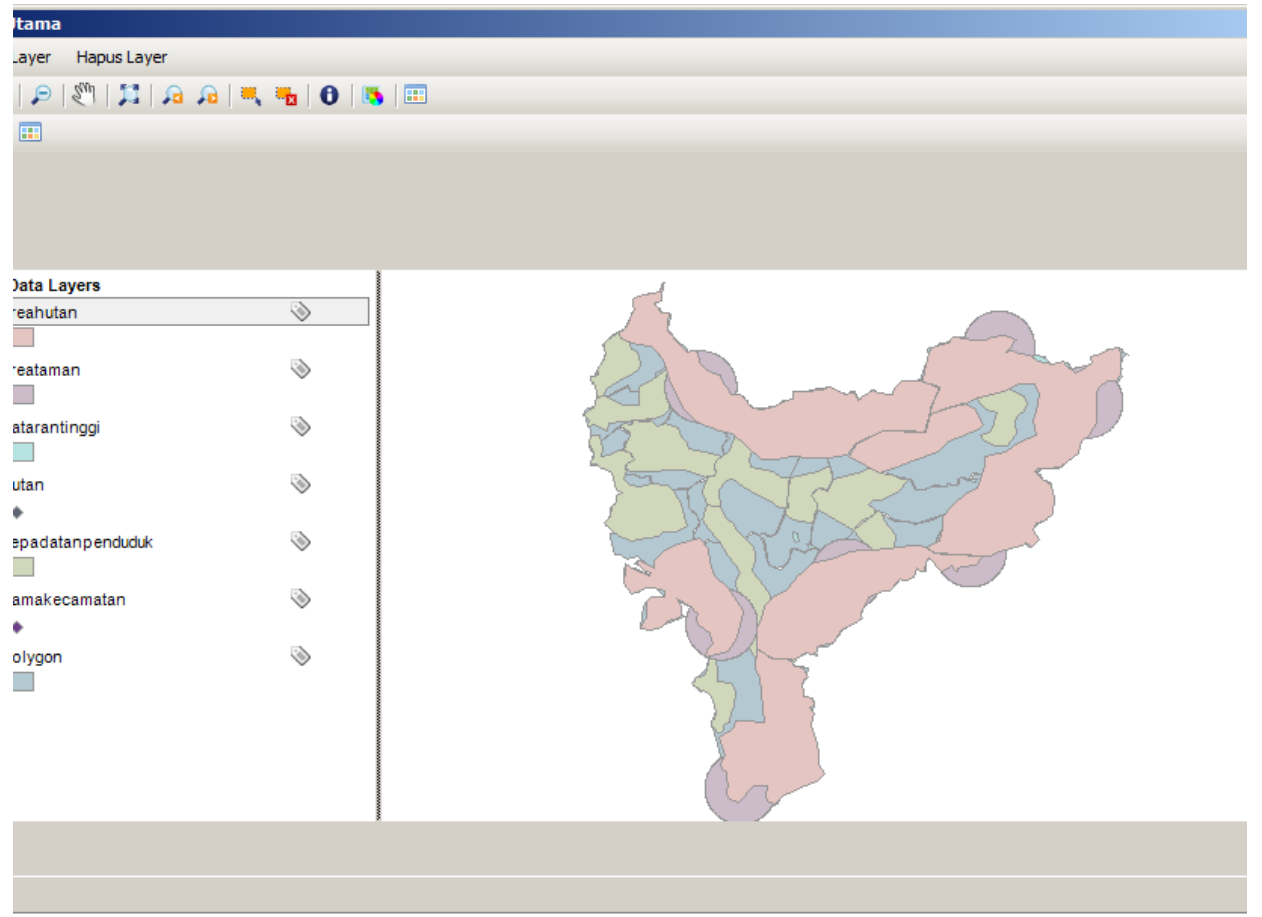

Gambar 13. Tampilan Aplikasi

Hasil ModelBuilder kemudian di-preview dan ditambahkan theme area taman yang berfungsi untuk mengetahui letak taman yang sudah dibangun dan berapa luas area kawasan yang dipengaruhi, seperti tampak pada gambar 14.

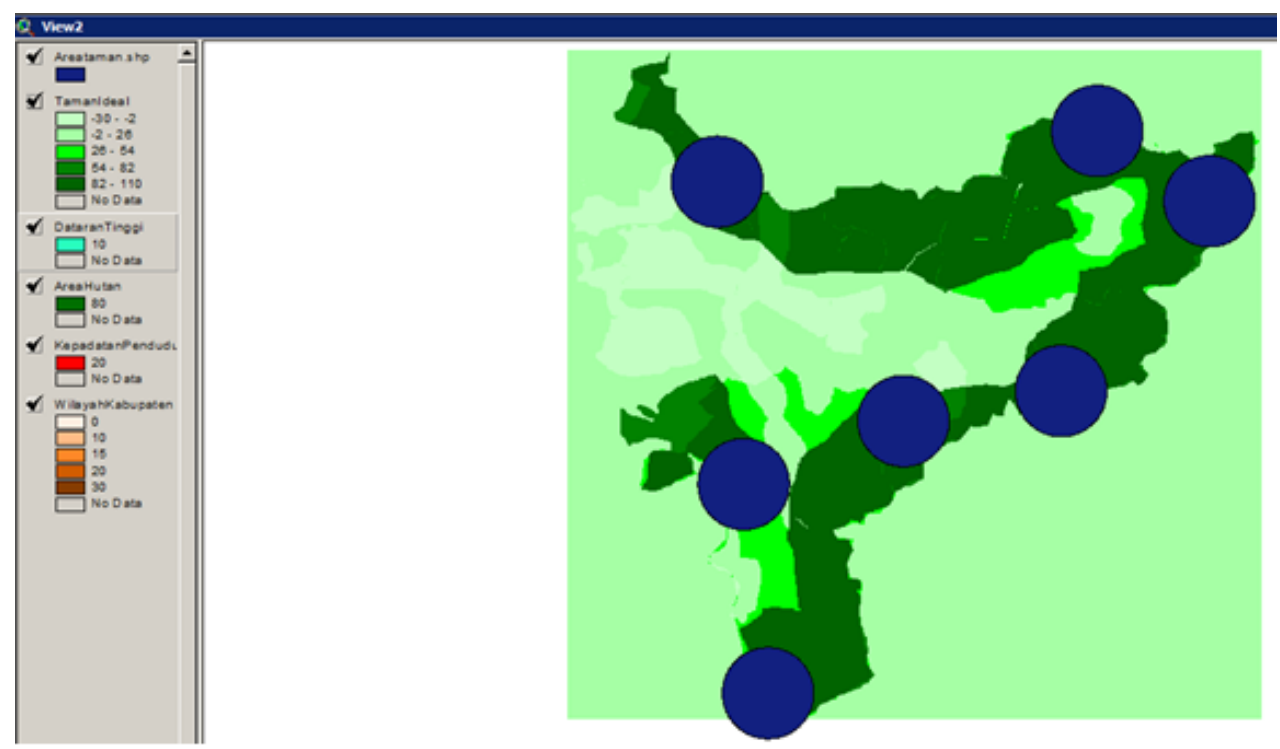

Gambar 14. Hasil Analisis Spasial

Dari analisis tersebut diperoleh daerah dengan kisaran skor tertentu. Skor hijau terang menunjukkan bahwa penentuan lokasi taman ideal tidak cocok karena dipengaruhi beberapa 
faktor seperti tanah wilayah, kepadatan penduduk, area hutan, dan dataran tinggi. Skor hijau tua menunjukkan penentuan taman ideal sangat cocok karena kawasan hutan yang masih dominan dan jauh dari kepadatan penduduk.

Ada tiga daerah dengan tanda persegi panjang berwarna merah yang memenuhi pemetaan lokasi taman ideal seperti ditunjukkan pada Gambar 15. Daerah tersebut masih didominasi area hutan dan masing-masing daerah juga tidak dekat dengan taman lain yang sudah ada.

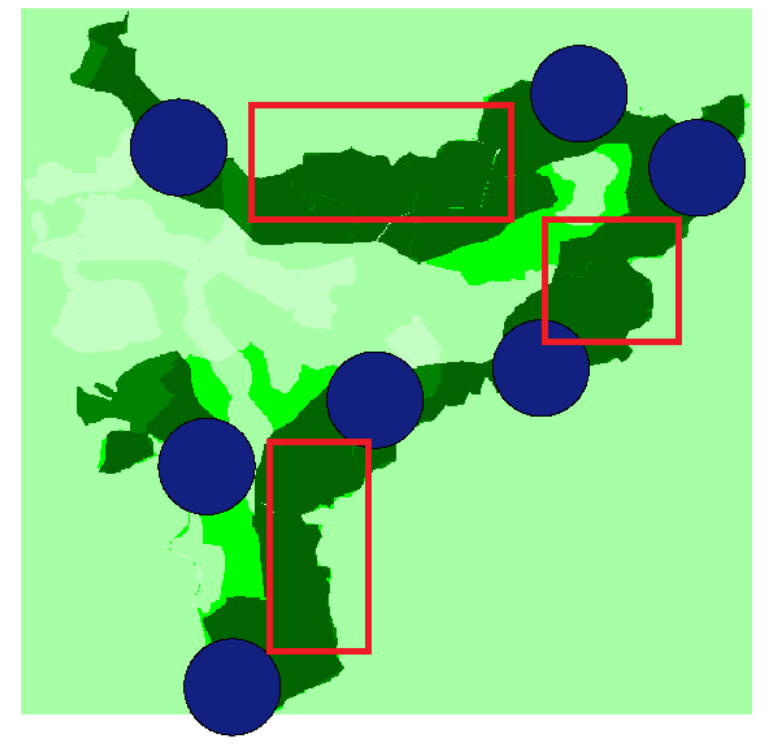

Gambar 15. Hasil Analisis Spasial Pemetaan Lokasi Taman Ideal

Hasil analisis data spasial ini mencakup proses overlay atau tumpang tindih dari beberapa tema yang memiliki kesamaan dari sistem proyeksi maupun kesamaan dalam kualitas atau skala gambar. Proses tumpang tindih tersebut seringkali digunakan untuk memperoleh informasiinformasi baru berdasarkan informasi yang telah dimiliki oleh tema-tema yang ditumpangtindihkan. Dalam hal ini theme yang dijumlahkan antara lain: Area Hutan, dataran tinggi, Kepadatan penduduk, dan Wilayah. Selain itu hasil analisis lokasi ideal taman nasional yang diperoleh lebih optimal dalam melihat sektor basis dan keunggulan suatu wilayah dengan menjumlahkan beberapa theme yang ditumpangtindihkan. Hal ini sejalan dengan penelitianpenelitian terdahulu yang telah dilakukan oleh Hazrin, et.al. (2016), Bunch, et.al. (2012), Penelitian Hassaan (2015), Whanda, et.al. (2015) dan Umar, et.al. (2015) dimana hasil dari GIS digunakan untuk menganalisis spasial lokasi yang tepat berkaitan dengan kriteria dievaluasi dan indeks lokasi optimal.

\section{KESIMPULAN}

Berdasarkan hasil penelitian dan analisis spasial maka dapat disimpulkan sebagai berikut: a) Hasil analisis lokasi ideal taman nasional yang diperoleh lebih optimal dalam melihat sektor basis dan keunggulan suatu wilayah dengan menjumlahkan beberapa theme yang ditumpangtindihkan; b) pemetaan lokasi ideal untuk taman nasional dapat dianalisis dengan menggunakan aplikasi ArcView GIS 3.3 dengan memanfaatkan komponen yang diimpor seperti geoprocessing, model builder dan spatial analyst. Melalui proses arithmatic overlay yang ada pada model builder, kita dapat menentukan lokasi ideal yang cocok dengan menggabungkan themetheme yang sudah dilengkapi dengan database; c) database menjadi patokan yang berisi informasi dari hasil digitasi yang dilakukan. Tanpa informasi yang ada akan sulit sekali menentukan daerah lokasi ideal untuk taman nasional. 


\section{SARAN}

Dari hasil penelitian ini masih terdapat beberapa kekurangan dan dimungkinkan untuk melakukan pengembangan lebih lanjut. Beberapa saran yang perlu penulis sampaikan adalah : a) dari segi aplikasi, masih ada kekurangan yaitu tidak adanya fitur geoprocessing pada aplikasi, padahal fitur ini sangat diperlukan sedangkan aplikasi ArcView GIS 3.3 mendukung untuk mempermudah proses digitasi; b) tentunya pembuatan aplikasi sangat sulit jika menggunakan koding, sehingga mungkin terdapat kesalahan-kesalahan kecil yang harus diperbaiki.

\section{UCAPAN TERIMA KASIH}

Penulis mengucapkan terima kasih kepada STMIK Pontianak yang telah memberi dukungan financial terhadap penelitian ini.

\section{DAFTAR PUSTAKA}

[1] Hazrin, M., Hiong H. G., Jai, N., Yeop, N., Hatta, M., Paiwai, F., Joanita, S., Othman, W., 2016, Spatial Distribution of Dengue Incidence: A Case Study in Putrajaya, Journal of Geographic Information System, No. 1, Vol. 8, Hal. 89-97.

[2] Bunch, M. J., Kumaran, T. V., Joseph, R., 2012, Using Geographic Information Systems (GIS) For Spatial Planning and Environmental Management in India: Critical Considerations, International Journal of Applied Science and Technology, No. 2, Vol. 2, Hal. 40-54.

[3] Hassaan, M. A., 2015, a GIS-Based Suitability Analysis for Siting a Solid Waste Incineration Power Plant in an Urban Area Case Study: Alexandria Governorate, Egypt, Journal of Geographic Information System, No. 6, Vol. 7, Hal. 643-657.

[4] Whanda, S., Sani, Y., Bulus, G., 2015, Modelling of Potential Pipeline Impact Radius and High Consequence Area in a Wetland Sub-Region of Nigeria, Journal of Geographic Information System, No. 6, Vol. 7, Hal. 692-709.

[5] Umar, A. A., Adepoju, M. O., Adesina, E. A., Bamgbose, M. O., 2015, Optimal Location Determination of Some Public Facilities within Minna Metropolis: A Geospatial Technique Approach, Journal of Geographic Information System, No. 6, Vol. 7, Hal. 658-666.

[6] Budiyanto, E., 2004, Sistem Informasi Geografis Menggunakan MapInfo, Penerbit Andi, Yogyakarta.

[7] Wiles, T., Mallard, J., 2008, Automating Tasks with ModelBuilder in ArcGIS, International Association of Crime Analyst's Conference (IACA) in St. Petersburg, Florida, 14 Oktober 2008.

[8] Pressman, R. S., Maxim, B. R., 2014, Software Engineering: A Practitioner's Approach 8th Edition, McGraw-Hill Education, New York.

[9] Prahasta, E., 2005, Konsep-Konsep Dasar Sistem Informasi Geografis, CV. Informatika, Bandung. 